\title{
Enchytraeid abundance in Araucaria Mixed Forest determined by cold and hot wet extraction
}

\author{
C. C. Niva, ${ }^{a, b}$, R. M. Cezar, P. M. Fonsecac , M. R. G. Zagatto, \\ E. M. Oliveira , E. F. Bush ${ }^{c}$, L. A. Clasen ${ }^{d}$ and G. G. Brown \\ aPrograma de Pós-graduação em Gestão Ambiental, Universidade Positivo - UP, Curitiba, PR, Brazil

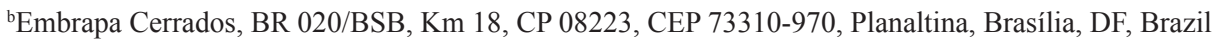 \\ 'Programa de Pós-graduação em Ciência do Solo, Setor de Ciências Agrárias, Universidade Federal do Paraná - UFPR, \\ Rua dos Funcionários, 1540, CEP 80035-050, Curitiba, PR, Brazil \\ dPontifícia Universidade Católica do Paraná - PUC-PR, Rua Imaculada Conceição, 1155, \\ CEP 80215-901, Curitiba, PR, Brazil

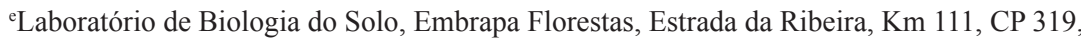 \\ CEP 83411-000, Colombo, PR, Brazil \\ *e-mail: cintiacn@gmail.com
}

Received: May 12, 2014 - Accepted: September 16, 2014 - Distributed: November 30, 2015 (With 3 figures)

\begin{abstract}
Enchytraeids are small oligochaetes found worldwide in soils with sufficient moisture and organic matter, but scarcely studied in the Southern hemisphere. This is the third study on enchytraeid abundance in Brazil using wet extraction and the first carried out in Araucaria Mixed Forest (subtropical region). The sampling and extraction were based on the standard method ISO 23611-3/2007 using an adapted split soil corer and wet extraction with and without heat to assess the abundance of enchytraeids in a forest fragment at Embrapa Forestry in Colombo, Paraná State. The samplings were performed in 3 occasions between September 2011 and April 2012. The average numbers estimated by each method varied from appr. 2.000-12.000 (cold) and 5.000-12.000 ind./ $\mathrm{m}^{2}$ (hot), respectively, with a maximum of 44.000 ind./ $\mathrm{m}^{2}$ in one of the samples, the highest value reported so far in Brazil. The hot extraction was more advantageous, given the speed and preservation of the specimens in vivo, allowing taxonomic identification. Advantages and disadvantages of wet extractions compared to handsorting and formol methods are also discussed. Guaranidrilus, Hemienchytraeus, Enchytraeus, Fridericia and Achaeta were the genera identified in the samples.
\end{abstract}

Keywords: Enchytraeidae, Oligochaeta, extraction methods, Araucaria, subtropical.

\section{Abundância de enquitreídeos na Floresta Ombrófila Mista determinada por extração úmida quente e fria}

\section{Resumo}

Os enquitreídeos são pequenos oligoquetas encontrados no mundo todo em solos com suficiente umidade e matéria orgânica, porém muito pouco estudados no hemisfério Sul. Este é o terceiro estudo sobre a abundância de enquitreídeos no Brasil utilizando o método de extração úmida e o primeiro realizado em Floresta Ombrófila Mista (região subtropical). A amostragem e extração foram baseadas no método padrão ISO 23611-3/2007, utilizando-se um trado desmontável adaptado e extração úmida com e sem aquecimento para acessar a abundância de enquitreídeo em um fragmento de floresta na Embrapa Florestas em Colombo, Paraná. As amostragens foram realizadas em três ocasiões entre setembro, 2011 e abril 2012. Os números médios estimados através de cada método variaram de 2.000-12.000 (frio) e 5.000-12.000 ind./ $\mathrm{m}^{2}$ (quente), respectivamente, e o máximo de 44.000 ind./ $\mathrm{m}^{2}$ em uma das amostras, o mais alto já relatado no Brasil. A extração quente foi a mais vantajosa, considerando a rapidez e preservação dos exemplares in vivo. As vantagens e desvantagens das extrações úmidas comparadas aos métodos de triagem manual e extração com formol foram discutidas. Os gêneros Guaranidrilus, Hemienchytraeus, Enchytraeus, Fridericia e Achaeta foram identificados nas amostras.

Palaras-chave: Enchytraeidae, Oligochaeta, métodos de extração, Araucária, subtropical. 


\section{Introduction}

Enchytraeids (Annelida, Oligochaeta, Enchytraeidae), also known as potworms, are small worms of about 2 to $20 \mathrm{~mm}$ body length found in soils with sufficient moisture, organic matter and oxygen, but are also found in freshwater and marine habitats. They are known to play important roles in soil processes (Didden, 1993; Laakso and Setälä, 1999) and has been used as bioindicators of soil quality (Jänsch et al., 2005) and in ecotoxicological studies (Didden and Römbke, 2001).

Studies on abundance and diversity on enchytraeids, and other soil fauna in the tropics, are important to understand their role in maintaining or improving soil fertility through interaction with the decomposition and nutrient cycling processes allowing comparisons to temperate regions (Römbke, 2007; Alho, 2008). In Europe, enchytraeid abundance may be high, reaching 300.000 individuals per square meter as reported by Peachey (1963) in soils rich in organic matter but, generally, it is reported to range between 5.000 and 143.000 (Didden, 1993) with annual average of 20.000 to 60.000 according to Jänsch et al. (2005). In the tropics, data on abundance and diversity as well as on the usefulness of the enchytraeids in soil biological classification and in the monitoring of anthropic effects is practically unknown (Römbke, 2007; Schmelz et al., 2013).

Soil fauna can be assessed by several methods according to their body diameter. The macrofauna (body diameter $>2 \mathrm{~mm}$ ) is handsorted with the naked eyes from soil monoliths of $0.25 \mathrm{~m}^{2} \times 0.30 \mathrm{~m}$ or bigger (e.g. Baretta et al., 2010). The mesofauna (body diameter 0.2 to $2 \mathrm{~mm}$ ) can be extracted from soil samples of smaller size in dry funnels heated with a lamp (e.g. Moço et al., 2005). Another method is the pitfall traps for invertebrates living on the soil surface (e.g. Antoniolli et al., 2006). In turn, in formol extraction, the worms are forced to come to the soil surface because of the irritating effect of the formalin applied on the soil. Hansorting and formol extraction are recommended for earthworm sampling (ISO, 2002). These methods are useful for ecological studies and for the assessment of biological quality of the soil, e.g. comparing natural, agricultural and urban systems. Enchytraeid abundance and diversity, however, cannot be properly assessed by these methods, basically because of three reasons: 1) most of these potworms cannot be seen with the naked eyes in handsorting and formol extraction, 2) they desiccate easily and die with dry heat in funnels, and 3) their mobility on soil surface to fall in a trap is almost null. The critical point, however, is because enchytraeids have to be identified in vivo under an optic microscope by observing their internal organs through the transparent body wall (Schmelz and Collado, 2010; Niva et al., 2010). Therefore, the abovementioned methods are not adequate, since the organisms undergo a fixation process which makes them opaque, preventing the identification. For enchytraeids, a wet method of extraction is needed to improve their survival and live preservation and allow more accurate investigation. The original wet extraction systems for enchytraeids described by Nielsen
(1952) and O'Connor (1955) were based on the nematode extraction method which uses plenty of water for the process. Both methods immerse soil samples in water inside a funnel and use an incandescent lamp on the top of the sample. The heat gradient produced by the lamp induce the worms to move downwards in the sample, so that they can be collected after a few hours by opening the valve linked to the inferior extremity of the funnel, where the water should be colder until the end of the extraction (as shown in Figure 1). Graefe (1984 apud ISO, 2007; Kobetičová and Schlaghamerský, 2003), however, adapted the extraction method without the heating by prolonging the extraction period. Later on, Kobetičová and Schlaghamerský (2003) and Panchenko (2006) compared hot and cold extraction, the first observed a higher number of enchytraeids when cold method was used for $24 \mathrm{~h}$, while the second, obtained only a slightly higher efficiency with cold method performed for 6 days. Since 2007, the standardized method ISO 23611-3 (ISO, 2007) describing the sampling and extraction method for enchytraeids has been available.

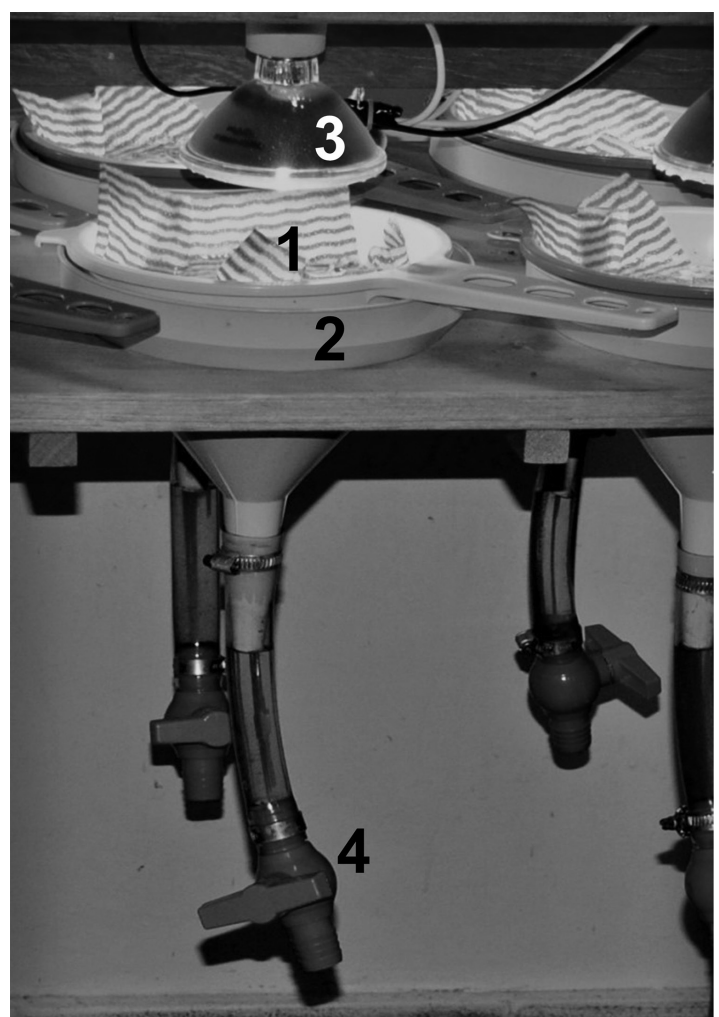

Figure 1. Wet extraction device with heating for enchytraeids. The soil sample is placed in a plastic sieve (15 cm diameter) lined with a porous flannel (1) which is kept submerged in mineral water fulfilling the funnel of $19 \mathrm{~cm}$ diameter (2). The lamp of $75 \mathrm{~V}$ (3) heats the sample forcing the enchytraeids to move downwards to the water and fall by gravity into the plastic valve (4) attached to the funnel outlet by a plastic hose. The enchytraeids are easily collected by opening the valve after a few hours. 
Römbke et al. (2007) and Römbke and Meller (1999), in their pioneering studies in South America, evaluated enchytraeid abundances in Brazil obtaining average abundances between 1500-3900 individuals per square meter (ind. $\mathrm{m}^{2}$ ) in Mata Atlântica soils, Southern region (Römbke et al., 2007) and 3900-4600 in Amazon (Römbke and Meller, 1999). In both cases, the recommended extraction period with the cold method was 3 to 5 days, in accordance with the guideline ISO 23611-3 (ISO, 2007). A wet funnel method with heating has also been used for ecological studies with enchytraeids and, so far, comparison of methods showed that extraction either with or without heating can be efficiently used for enchytraeids, each with only slight differences in the results (Kobetičová and Schlaghamerský, 2003; Panchenko, 2006). Our experience with the cold extraction method with soil samples from Embrapa Florestas, Southern Brazil, was not satisfactory because of frequent high mortality of the worms.

Although still only scarcely studied, Brazil has the best known enchytraeid diversity in the Southern Hemisphere (Schmelz et al., 2013). However, studies on their ecology using standardized methods and thus, globally comparable results, are restricted to a couple of publications (Römbke and Meller, 1999; Römbke et al., 2007) which used the cold wet extraction. In South America, there are a few other reports on abundance of enchytraeids, which numbers were determined by handsorting, but taxonomic groups were not assessed (Sturm, 1978; Vaçulik et al., 2004; López et al., 2005; Aquino et al., 2008; Manetti et al., 2010).

Therefore, the objective of this study was to compare the efficiency of cold and hot wet extractions in the abundance determination of enchytraeids in a fragment of Araucaria Mixed Forest in Southern Brazil. The efficiency of other two methods commonly used for bigger oligochaetes (earthworms), the handsorting of soil monoliths and formol extraction were also compared. This is the first time that the size of a local enchytraeid population is assessed in this type of forest. It is also the first report of the hot wet extraction for enchytraeids in South America. The advantages and disadvantages in abundance estimation of these methods are discussed.

\section{Material and Methods}

\subsection{Study site}

The area of study was a permanent parcel of forest inventory of Araucaria Mixed Forest in an advanced succession stage at Embrapa Forestry, Paraná State, Southern Brazil. It is characterized by the presence of a pine tree, Araucaria angustifolia, which dominates the landscape of the forest. The site is localized at appr. $950 \mathrm{~m}$ of altitude, $25^{\circ} 18^{\prime} 55.95^{\prime \prime} \mathrm{S}$; $49^{\circ} 9^{\prime} 19.13^{\prime \prime} \mathrm{W}$, the climate is subtropical $\mathrm{Cfb}$, according to Köppen classification. The average temperature from 2007 to 2012 was $17^{\circ} \mathrm{C}$ ( 2 to $26^{\circ} \mathrm{C}$ ), but with sporadic occurrence of temperatures as high as $34{ }^{\circ} \mathrm{C}$ and below-zero $\left(-3{ }^{\circ} \mathrm{C}\right)$ usually with frost during winter, annual precipitation varied from 1200 to $2400 \mathrm{~mm}$. The soil is a dystrophic haplic cambisol
(pH $4.1\left(\mathrm{CaCl}_{2}\right) ; 3.3 \%$ carbon, $0.3 \%$ nitrogen; $50 \%$ sand, $44 \%$ clay, $6.5 \%$ silt).

\subsection{Sampling, extraction and counting}

According to literature, enchytraeid abundance in South America has been determined mainly by handsorting (e.g. Lopez et al., 2005; Vaçulik et al., 2004; Aquino et al., 2008), which is not the standardized recommended method to assess the population size of this group. The cold wet extraction, which is internationally recommended (ISO, 2007), has been used by some authors (Römbke and Meller, 1999; Römbke et al., 2007), but we found some difficulties with this method. For this reason, we compared the efficiency of 4 methods to assess enchytraeid population: the cold wet extraction, the hot wet extraction, based on the original method (O'Connor's, 1955) and also the handsorting and formol extraction, which are recommended for the earthworms (ISO, 2007).

Soil cores of $5.1 \mathrm{~cm}$ of diameter (area of $20.427 \mathrm{~cm}^{2}$ ) and $7 \mathrm{~cm}$ depth were collected with a split soil corer made of galvanized iron coupled inside with a PVC tube cut in two halves longitudinally (Niva et al., 2010) (as seen in Figure 2). Samples were collected at 8 points in duplicates (one for each extraction type), one beside the other, along two parallel transects at each sampling occasions in September (winter-spring) and November, 2011 (spring) and in April, 2012 (autumn), totalizing 48 samples. The sampling points were about 10-15 meters distant from each other on transects placed in an area of $1 \mathrm{ha}$. A distance of about 50 meters was left between the border of the forest and the sampling area to minimize edge effect.

Cold wet extraction was performed as described in ISO 23611-3/2007 (ISO, 2007) and Niva et al. (2010) with mineral water in a room with controlled temperature

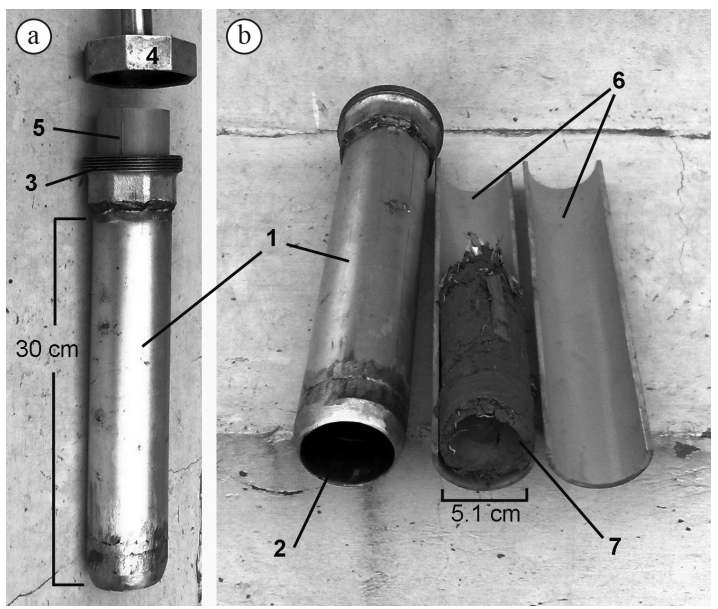

Figure 2. Split soil corer made of galvanized iron. (a) Soil corer showing PVC tube inside; (b) Soil corer and opened PVC tube with the soil sample. 1) cylinder of galvanized iron; 2) inferior opening with cutting edge for perforation; 3) superior opening; 4) screw cap of galvanized iron; 5) PVC tube coupled inside the cylinder; 6) two halves of the PVC tube; 7) soil sample inside the PCV tube. 
$\left(17 \pm 2{ }^{\circ} \mathrm{C}\right)$ for 3 days without water renewal during the process. The device for the hot extraction based on O'Connor's method (O'Connor, 1955) was built with plastic funnels ( $19 \mathrm{~cm}$ diameter) coupled with sieves inside as seen in Figure 1. A soil sample was placed in the sieve lined with a flannel and filled with mineral water which was heated by a lamp $(75 \mathrm{~W})$ for $3 \mathrm{~h}$, water temperature reaching $45-50{ }^{\circ} \mathrm{C}$ at the surface. Cold and hot extractions were carried out immediately after the sampling. Counting of the enchytraeid worms started soon after extraction and finished on the following day.

Additionally, 9 monoliths of $0.25 \times 0.25 \times 0.4 \mathrm{~m}$ were sampled for handsorting, and five liters of formalin $(0.5 \%)$ were applied directly on 9 plots of $0.25 \mathrm{~m}^{2}$ of the soil surface in adjacent points of the same area. In both cases, sampling was carried out only once in August, 2011.

\subsection{Taxonomic identification of worms}

The enchytraeid worms in good conditions, i.e. alive, healthy, damaged but with anterior portion intact were identified to genus level according to guidelines in Schmelz and Collado (2010) under a light microscope. Only the worms collected in the last sampling date were identified.

\section{Results}

The estimated total abundance obtained for winter-spring sampling in the fragment of Mixed Araucaria forest (hot and cold extracted together) was 202.667 individuals per square meter (ind. $\mathrm{m}^{2}$ ), for spring, 141.475 ind. $\mathrm{m}^{2}$,

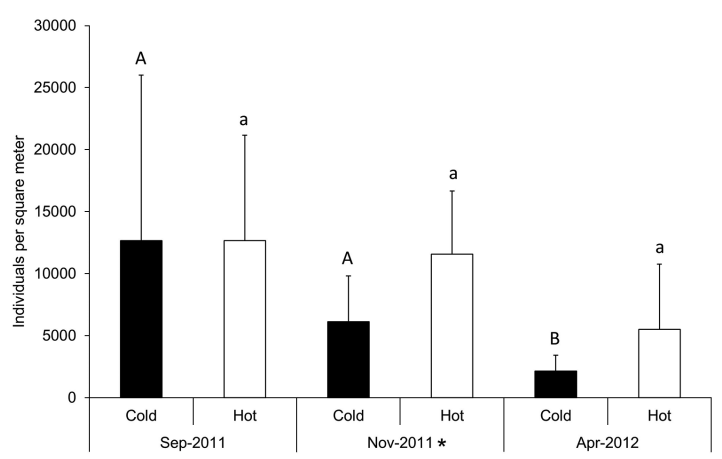

Figure 3. Average abundances of enchytraeids (ind. $\mathrm{m}^{2}$ ) ( \pm standard deviation) estimated by cold and hot extraction methods ( $\mathrm{n}=8$ at each sampling date). Statistical differences between sampling dates for cold extraction are shown by different capital letters and for hot extraction by different lowercase letters. Asterisk indicates statistical difference between hot and cold methods (ANOVA, Tukey; $\mathrm{p}<0.05$ ). and for autumn, 61.192 ind. $\mathrm{m}^{2}$ (as shown in Figure 3). The maximum average number of enchytraeid worms was 12.667 ind. $\mathrm{m}^{2}$, either by hot or cold extraction of the first sampling, and density reached a maximum of 44.058 ind. $\mathrm{m}^{2}$ in a single sample. By cold extraction, the samplings showed successively lower averages, on the other hand, by hot extraction, abundance decreased only in the autumn.

Abundances as obtained by cold and hot extractions were statistically different only in spring, but overall, the hot method generally yielded higher numbers. In contrast, the abundances determined by formol extraction $\left(5\right.$ ind. $\left.\mathrm{m}^{2}\right)$ and handsorting of monoliths (90 ind $\mathrm{m}^{2}$ ) were extremely low, even compared to the lowest estimation determined by wet extraction (2.142 ind. $\mathrm{m}^{2}$ ) in autumn (as shown in Figure 3).

The coefficient of variation between the samples was generally lower in hot than in cold extraction (as shown in Table 1) and all worms resultant of hot extraction had a healthy appearance, i.e. no amputation or deterioration, smooth and bright skin. Cold extraction for 3 days without exchange of water, on the other hand, resulted in 11-26\% of worms damaged drastically reducing the survival in the subsequent days as well.

The identification of the worms extracted in the third sampling revealed that the most abundant genus was Guaranidrilus (34\%), followed by Hemienchytraeus (26\%), Enchytraeus (16\%), Fridericia (14\%), Achaeta (10\%). Based on the variation of morphological characteristics of these specimens, about 11 different morpho-species were distinguished, the first genus being the most species-rich, with 4 species, and the others, 2 species.

\section{Discussion}

\subsection{Enchytraeid extraction method}

This is the third study on enchytraeid abundance in Latin America based on wet extraction and the first to be evaluated with heating. Opposing to Kobetičová and Schlaghamerský (2003) and Panchenko (2006), our data suggest a slightly better efficiency for the hot method. These differences may be related to the fact that the species composition in temperate regions, namely Europe, is different from South America and, consequently, temperature tolerance may also be different.

ISO 23611 (ISO, 2007) recommends 4-7 days of cold extraction for soil and 1-2 days for litter. We tested a 3 days cold extraction because longer periods previously tested were more deleterious, nevertheless, damaged worms reached $26 \%$, possibly because of oxygen deficiency or

Table 1. Coefficient of variation (C.V.) of enchytraeid abundance values and proportion of damaged specimens in each sampling date and extraction method.

\begin{tabular}{ccccc}
\hline & \multicolumn{2}{c}{ Cold extraction } & \multicolumn{2}{c}{ Hot extraction } \\
& C.V. (\%) Damaged (\%) & C.V. (\%) Damaged (\%) \\
\hline September 2011 & 105 & 11 & 67 & 0 \\
November 2011 & 60 & 11 & 44 & 0 \\
April 2012 & 60 & 26 & 95 & 0 \\
\hline
\end{tabular}


because of the neutral $\mathrm{pH}$ of water compared to $\mathrm{pH} 4$ of the natural soil. A prolonged cold extraction can be improved with the water exchange during the extraction period (ISO, 2007) and maintenance of the extraction unit under a cool room temperature. However, hot extraction for $3 \mathrm{~h}$ has shown advantages, such as speed and preservation of live specimens, especially when a cool room is not available. In any case, hot extraction should be carried out with caution if room temperature is higher than $25^{\circ} \mathrm{C}$. In that case, extraction should be shortened because the temperature gradient cannot be maintained properly (i.e. hot water on the sample and colder downward to the collector valve, and worms can die during the process). Another solution could be the cooling of the bottom of the soil sample.

Furthermore, because the occurrence of fragmenting species seems to be common in Brazil (Römbke et al., 2007), the cold extraction could possibly cause overestimation of the abundance if performed for more than 3 days. The fragmenting enchytraeids reproduce asexually splitting their body into several fragments which are able to regenerate new anterior and posterior portions in a few days (Christensen, 1964; Myohara et al., 1999; Niva et al., 2012). To avoid overestimation it is recommended to count only the enchytraeids with head, however, a prolonged cold extraction which gives enough time for a fragmenting worm to reproduce and regenerate, turns it difficult to distinguish worms with regenerated head from small intact worms.

\subsection{Abundance of enchytraeids in (sub)tropical soils}

The results of the two studies on enchytraeid abundance determined by wet extraction in South America published so far (Römbke and Meller, 1999; Römbke et al., 2007), point to low numbers of enchytraeids $(<10.000$ ind. $\mathrm{m}^{2}$ ) compared to temperate regions in Europe (Römbke, 2007; Schmelz et al., 2013). Jänsch et al. (2005) reported that, in general, numbers in temperate regions in Europe would range between 20.000-60.000 ind. $\mathrm{m}^{2}$. Didden (1993), compiling data of many other papers showed that in grasslands, abundances ranged 1.400-130.000, and, in forests, 3.800-143.000. In turn, Römbke (2007) reported that abundance in tropical region ranged between 2.000 and 7.000 ind. $\mathrm{m}^{2}$. The present study estimated an average density of appr. 12.000 ind. $\mathrm{m}^{2}$, among which a single sample reached appr. 44.000 ind. $\mathrm{m}^{2}$ in Mixed Araucaria Forest (subtropical area), suggesting that densities in South America may harbor habitats reaching numbers as high as in Europe if more habitats and biomes are studied, in agreement with the conclusions stated by Schmelz et al. (2013). These numbers are comparable to what Dezi et al. (2013) found in agricultural soils in India (16.000 ind. $\mathrm{m}^{2}$ ) and are higher than found by Chan and Heenan (1995) (2000 ind. $\mathrm{m}^{2}$ ) in arable lands in Australia.

Further studies included data on enchytraeid abundance determined by handsorting of soil monoliths in Brazil, such as Brown et al. (2001) who reported appr. 1400 ind. $\mathrm{m}^{2}$ in a conventional tillage with crop rotation in Paraná State and Aquino et al. (2008) who determined an average of 1818 ind. $\mathrm{m}^{2}$ of enchytraeids in a forest fragment at
Cerrado biome, in Mato Grosso state, Brazil. In Argentina, López et al. (2005) reported an abundance of 11.074 ind. $\mathrm{m}^{2}$ in pastures and, Manetti et al. (2010), appr. 750 ind. $\mathrm{m}^{2}$ in no-tillage cropping system. In the present study, handsorting and formol extraction showed, respectively, abundances 400 and 24 times smaller than the least abundant sampling date, strongly suggesting that an adequate, preferably standardized, sampling and extraction method is important to generate more reliable and globally comparable abundance estimations. Handsorting of monoliths with the naked eyes has shown the importance of enchytraeids in South America in some situations, however, this method favors the counting of the biggest worms only, and turns the counting of smaller worms impracticable. Therefore, handsorting with the naked eyes can underestimate the abundance of enchytraeids in a given area.

On the other hand, Vaçulik et al. (2004) reported expressive 270.000 ind. $\mathrm{m}^{2}$ in samples of a rock savanna inselberg in French Guiana, where bromeliads grow on rocks covered by filamentous cyanobacteria. These authors counted the worms under a stereomicroscope with a meticulously handsorting humus profiles. In addition, Sturm (1978) reported the equivalent to 179.500 ind. $\mathrm{m}^{2}$ in Paramo soils at high mountains of $3230 \mathrm{~m}$ a.s.1. in Colombia, as recalculated by Schmelz et al. (2013). These densities are similar to those obtained in acid soils of coniferous forests in Europe and peatlands (Didden, 1993), which can reach 300.000 ind. $\mathrm{m}^{2}$ (Peachey, 1963). Despite the accuracy of the numbers presented by these studies, the handsorting of samples under a microscope is excessively time-consuming. Therefore, the use of a standardized method is recommended and, as importantly, to allow examination of live specimens for taxonomic identification. As a common practice, handsorting with the naked eye of soil monoliths and the extraction by dry funnel, are immediately followed by fixation of the specimens, which makes taxonomic investigation much more difficult for enchytraeids.

The decreasing abundances shown by Figure 3 from the first to the last sampling date may suggest a seasonal effect on abundance. In fact, soil moisture was $8 \%$ lower in April, when precipitation was lower than in November of previous year. Enchytraeids need moisture in the soil, since the epidermis is permeable to water and can desiccate easily (Dash, 1983; Didden, 1993). Therefore, lower soil moisture may influence enchytraeid population negatively, as reported by others (Beylich and Achazi, 1999; Maraldo et al., 2008). However, more data are required before a conclusion can be drawn for the present data.

\subsection{Diversity of enchytraeids}

The diversity of species found in South America is comparable to temperate regions but species composition is different (Römbke, 2007). Compared to the diversity found by Römbke et al. (2007) in a Mata Atlântica area close to the coast of Paraná State, basically the same genera were found, except for Xetadrilus (= genus X in Römbke et al., 2007), a genus posteriorly described by Schmelz et al. (2011). 
The genus Guaranidrilus, which is considered a true South American group, and Hemienchytraeus, a cosmopolitan group (Schmelz et al., 2013), were dominant in the Mixed Araucaria Forest. Achaeta, Fridericia and Enchytraeus, which are commonly found in temperate regions were also present. In Amazonian forests and Paramo regions in Colombia, Guaranidrilus was also a dominant genus (Römbke and Meller, 1999; Römbke, 2007). In Mata Atlantica, Fridericia was found almost exclusively in pastures, Enchytraeus was less often in older forests, while Guaranidrilus tended to be more frequent in primary forests. In the present study, Guaranidrilus was more abundant (34\%) than Enchytraeus and Fridericia together $(30 \%)$, possibly suggesting a good condition of the habitat function of the soil in the forest studied, however with some degree of disturbance. The fact that the fragmenting species Enchytraeus dudichi s.l. Dózsa-Farkas, 1995 was mostly present among the Enchytraeus found in the samples reinforces the idea of disturbance since it can be considered as r-strategist (Graefe and Schmelz, 1999).

Naidids are worms commonly found in aquatic environments, in some cases composing more than 50\% of the Oligochaeta assemblages, such as reported by Behrend et al. (2009) for investigations in the Upper Paraná River floodplain in Mato Grosso do Sul State. Interestingly, naidids were also present in some samples of our study, amounting 1-3\% of the total of the wet extracted oligochaetes. Naidids were also found in Amazon and Mata Atlântica (Römbke and Meller, 1999; Römbke et al., 2007; Collado and Schmelz, 2000) and their presence considered as a possible sign of disturbance (Römbke et al., 2007). Most of them probably belong to the genus Pristina, which is considered an "aquatic" group. It seems that the occurrence of these asexual small oligochaetes in soil habitats is common in Brazil (Collado and Schmelz, 2000; Römbke et al., 2007).

In conclusion, the hot wet extraction was more advantageous than cold extration, given the speed and preservation of the specimens in vivo, resulting in a maximum average of 12.000 ind. $\mathrm{m}^{2}$ in a fragment of Mixed Araucaria Forest and five different enchytraeid genera, among which Guaranidrilus was the dominant one.

\section{Acknowledgements}

This study was supported by PNPD/CNPq/MCT/FINEP and Embrapa Forestry. Authors are grateful to Dr. R.M. Schmelz for guidance in the taxonomic identification.

\section{References}

ALHO, C.J.R., 2008. The value of biodiversity. Brazilian Journal of Biology $=$ Revista Brasileira de Biologia, vol. 68, no. 4, suppl., pp. 1115-1118. http://dx.doi.org/10.1590/S151969842008000500018. PMid:19197481.

ANTONIOLLI, Z.I., CONCEIÇÃO, P.C., BÖCK, V., PORT, O., SILVA, D.M. and SILVA, R.F., 2006. Método alternativo para estudar a fauna do solo. Ciência Florestal, vol. 16, no. 4, pp. 407-417.

AQUINO, A.M., SILVA, R.F., MERCANTE, F.M., CORREIA, M.E.F., GUIMARÃES, M.F. and LAVELLE, P., 2008. Invertebrate soil macrofauna under different ground cover plants in the no-till system in the Cerrado. European Journal of Soil Biology, vol. 44, no. 2, pp. 191-197. http://dx.doi.org/10.1016/j.ejsobi.2007.05.001.

BARETTA, D., BROWN, G.G., CARDOSO, E.J.B.N., 2010. Potencial de la macrofauna y de otras variables edáficas como indicadoras de la calidad del suelo en áreas con Araucaria angustifolia. Acta Zoológica Mexicana, vol. 26, no. 2, pp. 135-150.

BEHREND, R.D.L., FERNANDES, S.E.P., FUJITA, D.S, and TAKEDA, A.M., 2009. Eight years of monitoring aquatic Oligochaeta from the Baía and Ivinhema Rivers. Brazilian Journal of Biology = Revista Brasileira de Biologia, vol. 69, no. 2, suppl., pp. 559-571. http://dx.doi.org/10.1590/S1519-69842009000300011. PMid:19738963.

BEYLICH, A. and ACHAZI, R.K., 1999. Influence of low soil moisture on enchytraeids. Newsletter on Enchytraeidae, vol. 6, pp. 49-58.

BROWN, G.G., PASINI, A., BENITO, N.P., DE AQUINO, A.M. and CORREIA, M.E.F., 2001. Diversity and functional role of soil macrofauna communities in Brazilian no tillage agroecosystems: a preliminary analysis. In: International Symposium on Managing Biodiversity in Agricultural Ecosystems, 2001, Montreal. Londrina: Embrapa Soja, pp. 8-10.

CHAN, K.Y. and HEENAN, D.P., 1995. Occurrence of enchytraeid worms and some properties of their casts in an Australian soil under cropping. Soil Research, vol. 33, no. 4, pp. 651-657.

CHRISTENSEN, B., 1964. Regeneration of a new anterior end in Enchytraeus bigeminus (Enchytraeidae, Oligochaeta). Videnskabelige Meddelelser Dansk Naturhistorisk Forening, vol. 127, pp. 259-273.

COLLADO, R. and SCHMELZ, R.M., 2000. Pristina silvicola and Pristina terrena spp. nov., two new soil-dwelling species of Naididae (Oligochaeta, Annelida) from the tropical rain forest near Manaus, Brazil, with comments on the genus Pristinella. Journal of Zoology, vol. 251, no. 4, pp. 509-516. http://dx.doi. org/10.1111/j.1469-7998.2000.tb00806.x.

DASH, M.C., 1983. The biology of Enchytraeidae. Dehradum: International Book Distributors.

DEZI, S., LAL, D. and LAL, V.B., 2013. Enchytraeids sustainability and tolerance against agro-chemicals in Zea mays cropland. The Bioskan, vol. 8, no. 1, pp. 213-217.

DIDDEN, W.A.M., 1993. Ecology of terrestrial Enchytraeidae. Pedobiologia, vol. 37, pp. 2-29.

DIDDEN, W. and RÖMBKE, J., 2001. Enchytraeids as indicator organisms for chemical stress in terrestrial ecosystems. Ecotoxicology and Environmental Safety, vol. 50, no. 1, pp. 25-43. http://dx.doi. org/10.1006/eesa.2001.2075. PMid:11534950.

GRAEFE, U. and SCHMELZ, R.M., 1999. Indicator values, strategy types and life forms of terrestrial Enchytraeidae and other microannelids. In: R.M. SCHMELZ and K. SÜHLO, eds. Proceedings of the 3rd International Symposium on Enchytraeidae, 1999, Osnabrück, Germany. Osnabrück: Universitätsverlag Rasch, pp. 59-67. Newsletter on Enchytraeidae, no. 6.

INTERNATIONAL ORGANIZATION FOR STANDARDIZATION - ISO, 2002. ISO 23611-1:2002: soil quality: sampling of soil 
invertebrates. Part 1: hand-sorting and formalin extraction of earthworms. Genebra: ISO.

INTERNATIONAL ORGANIZATION FOR STANDARDIZATION - ISO, 2007. ISO 23611-3: soil quality: sampling of soil invertebrates. Part 3: sampling and soil extraction of enchytraeids. Genebra: ISO.

JÄNSCH, S., RÖMBKE, J. and DIDDEN, W., 2005. The use of enchytraeids in ecological soil classification and assessment concepts. Ecotoxicology and Environmental Safety, vol. 62, no. 2, pp. 266-277. http://dx.doi.org/10.1016/j.ecoenv.2004.10.025. PMid:15919116.

KOBETIČOVÁ, K. and SCHLAGHAMERSKÝ, J., 2003. On the efficiency of three schemes of enchytraeid wet funnel extraction. Newsletter on Enchytraeidae, vol. 8, no. 1, pp. 25-31.

LAAKSO, J. and SETÄLÄ, H., 1999. Sensitivity of primary production to changes in the architecture of belowground food webs. Oikos, vol. 87, no. 1, pp. 57-64. http://dx.doi.org/10.2307/3546996.

LÓPEZ, A.N., VINCINI, A.M., CLEMENTE, N.L., MANETTI, P.L., CARMONA, D.M. and CASTILLO, H.A.A., 2005. Densidad estacional y distribuición vertical de los Enchytraeidae (Annelida: Oligochaeta) em diferentes sistemas de producción. Ciencia del Suelo, vol. 23, pp. 115-121.

MANETTI, P.L., LOPEZ, A.N., CLEMENTE, N.L. and FABERI, A.J., 2010. Tillage system does not affect soil macrofauna in southeastern Buenos Aires province, Argentina. Spanish Journal of Agricultural Research, vol. 8, no. 2, pp. 377-384. http://dx.doi. org/10.5424/sjar/2010082-1189.

MARALDO, K., SCHMIDT, I.K., BEIER, C. and HOLMSTRUP, M., 2008. Can field populations of the enchytraeid, Cognettia sphagnetorum, adapt to increased drought stress? Soil Biology \& Biochemistry, vol. 40, no. 7, pp. 1765-1771. http://dx.doi. org/10.1016/j.soilbio.2008.02.016.

MOÇO, M.K., GAMA-RODRIGUES, E.F.D., GAMA-RODRIGUES, A.C.D. and CORREIA, M.E.F., 2005. Caracterização da fauna edáfica em diferentes coberturas vegetais na região norte fluminense. Revista Brasileira de Ciencia do Solo, vol. 29, no. 4, pp. 555-564. http://dx.doi.org/10.1590/S0100-06832005000400008.

MYOHARA, M., YOSHIDA-NORO, C., KOBARI, F. and TOCHINAI, S., 1999. Fragmenting oligochaete Enchytraeus japonensis: a new material for regeneration study. Development, Growth \& Differentiation, vol. 41, no. 5, pp. 549-555. http:// dx.doi.org/10.1046/j.1440-169x.1999.00455.x. PMid:10545027.

NIELSEN, C.O., 1952. Studies on Enchytraeidae 1: a technique for extracting Enchytraeidae from soil samples. Oikos, vol. 4, no. 2, pp. 187-196. http://dx.doi.org/10.2307/3564814.

NIVA, C.C., RÖMBKE, J., SCHMELZ, R.M. and BROWN, G.G., 2010. Enquitreídeos (Enchytraeidae, Oligochaeta, Annelida). In: F.M.S. MOREIRA, E.J. HUISING and D.E. BIGNELL, eds. Manual de biologia dos solos tropicais: amostragem e caracterização da biodiversidade. Lavras: UFLA, pp. 351-365.

NIVA, C.C., SCHMELZ, R.M. and BROWN, G.G., 2012. Notes on the reproduction, fragmentation and regeneration of Enchytraeus dudichi Dózsa-Farkas, 1995 found in Paraná State, Brazil. Landbauforschung - vTI Agriculture and Forestry Research, vol. 357, pp. 13-19. Newsletter on Enchytraeidae, no. 12.

O'CONNOR, F.B., 1955. Extraction of enchytraeid worms from a coniferous forest soil. Nature, vol. 175, no. 4462, pp. 815-816. http://dx.doi.org/10.1038/175815b0. PMid:14370225.

PANCHENKO, I.A., 2006. Comparison of two methods for extraction of enchytraeids. Entomological Review, vol. 86, no. S1, pp. S104-S106. http://dx.doi.org/10.1134/S0013873806100095.

PEACHEY, J.E., 1963. Studies on the Enchytraeidae (Oligochaeta) of moorland soil. Pedobiologia, vol. 2, pp. S81-S95.

RÖMBKE, J. and MELLER, M., 1999. Applied research on Enchytraeidae in Central Amazonia: project approach, methodology and first results. Newsletter on Enchytraeidae, vol. 6, pp. 69-75.

RÖMBKE, J., 2007. Enchytraeidae of tropical soils: state of the art, with special emphasis on Latin America. Folia Facultatis Scientiarium Naturalium Universitatis Masarykianae Brunensis: Biologia, vol. 110, pp. 157-181.

RÖMBKE, J., COLLADO, R. and SCHMELZ, R.M., 2007. Abundance, distribution and indicator potential of enchytraeid genera (Enchytraeidae, Clitellata) in secondary forests and pastures of the Mata Atlântica. Acta Hydrobioica Sinica, vol. 3, pp. 139-150.

SCHMELZ, R.M. and COLLADO, R., 2010. A guide to European terrestrial and freshwater species of Enchytraeidae (Oligochaeta). Soil Organisms, vol. 82, no. 1, pp. 1-176.

SCHMELZ, R.M., COLLADO, R. and RÖMBKE, J., 2011. Mata Atlantica enchytraeids (Parana, Brazil): a new genus, Xetadrilus gen. nov., with three new species, and four new species of Guaranidrilus Černosvitov (Enchytraeidae, Oligochaeta). Zootaxa, vol. 2838, pp. 1-29.

SCHMELZ, R.M., NIVA, C.C., RÖMBKE, J. and COLLADO, R., 2013. Diversity of terrestrial Enchytraeidae (Oligochaeta) in Latin America: current knowledge and future research potential. Applied Soil Ecology, vol. 69, pp. 13-20. http://dx.doi.org/10.1016/j. apsoil.2012.12.012.

STURM, H., 1978. Zur Ökologie der andinen Paramoregion. Biogeographica, vol. 14, pp. 1-121.

VAÇULIK, A., KOUNDA-KIKI, C., SARTHOU, C. and PONGE, J.F., 2004. Soil invertebrate activity in biological crusts on tropical inselbergs. European Journal of Soil Science, vol. 55, no. 3, pp. 539-549. http://dx.doi.org/10.1111/j.1365-2389.2004.00615.x. 